\title{
NILAI KARAKTER DALAM TRADISI ARI-ARI MEGANTUNG DI DESA BAYUNG GEDE, KINTAMANI, BANGLI, BALI
}

\author{
I Wayan Putra Yasa ${ }^{1}$ \\ yanputra666@gmail.com / putrayasa@undiksha.ac.id
}

\begin{abstract}
ABSTRAK
Masyarakat desa Bayung Gede yang ada di Kecamatan Kintamani, Bangli, Bali merupakan salah satu masyarakat desa Bali Aga yang memiliki tradisi daur hidup yang sangat unik yaitu Tradisi Ari-Ari Megantung. Tradisi Ari-ari Megantung dilaksanakan ketika ada bayi yang baru lahir kemudian ari-ari pembungkus bayi itu di taruh di dalam kuburan dengan cara digantung dalam sebuah batok kelapa. Tradisi ini sudah ada di desa Bayung Gede sejak keberadaan desa ini dan terus dilaksanakan secara turun temurun hingga saat ini.Tradisi ini memiliki nilai-nilai positif yang mempengaruhi kepribadian atau karakter penduduk di desa Bayung Gede sehingga mereka begitu menghargai kebudayaan dan adat yang dimilikinya.
\end{abstract}

Kata kunci: nilai, karakter, tradisi ari-ari megantung

\footnotetext{
${ }^{1}$ Dosen Jurusan Pendidikan Sejarah, FHIS-Undiksha
} 


\section{Pendahuluan}

Mengutif pernyataan Dr. Gardner dan Jewans (dalam Sudarta 2013:11) yang menyatakan "kelahiran bayi itu adalah merupakan kejadian yang sangat mengesankan bagi orangorang di zaman dulu.Karena keindahannya maka dianggaplah kejadian itu sebagai hal yang superhuman. Dipercayai pula bahwa suasana itu mengandung banyak bahaya sehingga untuk menghindari bahaya itu bermacam-macam tabu atau larangan diajukan". Kenyataan di atas meginsipirasi masyarakat untuk melakukan tindakan atau aktifitas budaya yang bisa melindungi dan menjadikan hari itu sebagai hari yang sangat penting dan bernilai bagi keluarganya. Maka bermunculanlah berbagai tradisi dalam menyambut kelahiran bayi.Tradisi yang ada di setiap daerah menunjukan karakter yang berbeda satu dan yang lainnya namun memiliki makna yang sama sebagai ungkapan rasa senang dan syukur atas kelahiran sang jabang bayi ke dunia.

Dalam ajaran agama Hindu upacara kelahiran bayi disebut dengan Jatakarma.Filosofis ajaran agama yang mendasari adalah kitab Atharwa Weda, Sukta 11 yang terdiri dari 6 sloka yang berisikan tentang doa untuk menyambut kelahiran bayi. Tetapi dalam konteks prakteknya ada perbedaan antara apa yang dilaksanakan di India sebagai pusat agama Hindu dengan yang terjadi di Indonesia dan Bali khususnya. Di Indonesia, upacara doa Atharwa Weda di atas tidak dipakai tetapi diganti dengan sejajen (Sudartha, 2013:13). Perbedaan ini menjadi bukti nyata bahwa ajaran Agama Hindu telah mengalami akulturasi dengan kebudayaan lokal di Indonesia sehingga bisa dilaksanakan mengikuti apa yang telah ada di masyarakat. Akulturasi adalah proses percampuran dua atau lebih kebudayaan asli dan kebudayaan luar dengan tidak meninggalkan unsurunsur kebudayaan asli pembentuknya.

Untuk kasus di Bali upacara jatakarma ini setiap daerah dilakukan dengan bentuk yang beranekaragam sesuai dengan konsep desa, kala dan patra atau menurutdesa mawacara (tata cara di desa bersangkutan). Namun tetap dengan dasar filosofi dasar menghormati catur sanak (empat saudara bayi) yang terdiri atas air ketuban, darah, ari-ari dan pusar.

Hal menarik dari upacara terhadap catur sanak khususnya ari-ari. Pada umat Hindu di India belum pernah ditemukan upacara atau doa mengenai ari-ari (Supartha, 2013:15). Namun, dalam masyarakat di Indonesia unsur ari-ari ini termasuk yang penting untuk ditangani dan diupacarai.Secara umum tradisi untuk menangangi ari-ari bisa di bagi menjadi dua yaitu metanem (dikubur) di samping pintu masuk ke dapur, dengan aturan jika bayinya lakilaki di kanan pintu dan jika perempuan di sebelah kiri pintu.Tradisi lainnya yaitu dilarung (dibuang kelaut), umumnya dilakukan oleh masyarakat pantai yang mengharapakan anaknya kelak menjadi orang yang berani dan bebas mengaruhi kehidupan.Namun hal menarik yang keluar dari keumuman itu ada di desa Bayung Gede, KintamaniBangli.Ari-ari bayi yang baru lahir ini tidak di kubur atau di buang ke laut 
namun digantungkan pada sebatang pohon sehingga tradisinya di sebut tradisi ari-ari megantung.

Tradisi ari-ari megantung menurut para tetua di desa Bayung Gede memiliki makna yang sama dengan bayi yang di buang di laut yakni mengharapkan anak-anak yang dilahirkan di Bayung Gede memiliki keberanian untuk mengarungi kehidupan. Mengapa digantung di dahan pohon bukak ini karena masyarakat Bayung Gede secara geografis tidak berada di pinggir laut atau pantai, sehingga harapan untuk memiliki generasi yang bisa mengaruhi dunia sama seperti orang laut, bedanya jika orang laut harapan itu dengan melarung air-ari bayinya ke laut, namun oang Bayung Gede ari-ari anaknya di gantung dengan harapan diterbangkan oleh angin.Alasan rasional lainnya adalah faktor keamanan, ini tidak bisa dilepaskan dari kebiasaan masyarakat Bayung Gede untuk memelihara binatang peliharaan seperti anjing dan babi.Binatang ini memiliki kebiasaan menggali dan mencari sesuatu yang dianggap bisa untuk dimakan.Oleh sebab itu untuk menghindari ari-ari bayi yang baru lahir itu dimakan oleh binatang maka timbullah ide untuk menaruhnya didahan pohon sehingga tidak bisa dijangkau oleh binatang itu.alasanalasan di atas baru sebatas pemikiran rasional yang berkembang di masyarakat secara luas. Persepsi yang berbeda itu berkembang karena tidak adanya bukti tertulis yang menjelaskan secara pasti tradisi ari-ari megantung yang ada di Bayung Gede.Walaupun demikian dalam sejarah bisa saja diterima sebagai tradisi lisan (oral history)sebagai salah satu sumber penulisan sejarah (Vansina, 2014).

\section{Metode Penelitian}

Penelitian ini adalah penelitian kualitatif yang bertujuan untuk memberikan gambaran yang holistik tentang Tradisi Ari-ari Megantung.Langkah penelitian dilaksanakan dengan prosedur yaitu penentuan lokasi yakni di desa Bayung Gede, Kintamani, Bangli, Bali.Sumber data berupa dokumen, informan dan artefak atau bukti pelaksanaan tradisi ari-ari megantung.Teknik pengumpulan data dilaksanakan dengan teknik studi dokumen, wawancara mendalam dan observasi langsung kelokasi penelitian.Tahap akhir penelitian dilaksanakan penulisan laporan dengan memakai teknik analisis data memakai analisis interaktif Miles dan Humerman (2009).

\section{Pembahasan}

1. Gambaran umum Tradisi Ari-ari Megantung

Pertanyaan bagaimana sebenarnya Tradisi Ari-ari Megantung tidak diketahui secara pasti.Menurut tokoh desa Bayung Gede tradisi ini sudah ada sejak keberadaan desa Bayung Gede itu berdiri. Tradisi ini berjalan secara turun temurun dengan mengikuti prosesi yang baku. Prosesi ari-ari megantung melalui rangkaian kegiatan yang dikenal dengan prosesi upacara, yaitu tahapan-tahapan dari tradisi itu dari awal sampai akhir.Prosesi upacara itu terbagi menjadi tiga tahapan yaitu persiapan, 
puncak upacara dan akhir dari upacara.Rangkaian upacara atau tradisi ini menjadi satu kesatuan yang tidak bisa dipisahkan. Seperti yang disampaikan oleh Koentjaraningrat (1984 : 190) upacara ritual adalah sistem aktifasi atau rangkaian tindakan yang ditata oleh adat atau hukum yang berlaku dalam masyarakat yang berhubungan dengan bagaimana macam peristiwa tetap yang biasanya terjadi pada masyarakat yang bersangkutan. Upacara ritual memiliki aturan dan tata cara yang telah ditentukan oleh masyarakat atau kelompok pencipta ritual tersebut, sehingga masing-masing ritual mempunyai perbedaan, baik dalam hal pelaksanaan ataupun perlengkapannya. Berdasarkan pada pendapat tersebut maka ritual ari-ari megantung yang ada di Bayung Gede pun sejatinya memiliki rangkaian dan peralatan yang jelas sebagai pembeda dengan aktifitas ritual yang lainnya.

Secara umum tradisi ari-ari megantung di desa Bayung Gede memiliki tahapan-tahapan pelaksanaan yang terangkai secara berurutan dari awal ketika bayi dilahirkan sampai pada keluarga itu dinyatakan sudah tidak cuntaka lagi. Tahapan rangkaian tradisi ini diuraikan lebih lanjut sebagai berikut.

Tahapan awal di maksud di sini adalah perlakuan dan persiapan yang dilakukan oleh sang ayah pemilik bayi terhadap ari-ari yang akan digantung.

a. Ketika sebuah keluarga memiliki bayi yang baru lahir maka ari-ari anak itu akan di bawa ke rumah orangtuanya. Sesampai di rumahnya ayah dari si bayi melakukan pembersihan terhadap ari-ari ini. Ari-ari ini dibersihkan sebersih mungkin dengan harapan kelak anak itu menjadi anak yang mencintai kebersihan dalam kehidupannya. Kebersihan memiliki makna bahwa sang anak akan menjadi anak yang memiliki pemikiran, fisik dan juga perilaku yang menghindari hal-hal negatif dalam kehidupan selanjutnya. Selain itu juga kebersihan bermaksud menghilangkan bekasbekas darah yang menempel pada ari-ari sehingga tidak kotor dan menimbulkan bau yang tidak sedap secara psikologi pemberihan ini juga sebagai pengejawantahan dari harapan-harapan tersebut di atas. Prosesi pembersihan ini dilakukan di paon (dapur) orangtuanya. Dapur dalam kehidupan masyarakat Bayung Gede memiliki fungsi yang sangat penting terutama berkaitan dengan proses daur hidup, seperti kelahiran, pernikahan, dan kematian. Oleh karena itu bangunan dapur menjadi sangat penting dalam struktur rumah masyarakat di sana. Berdasarkan hasil wawancara dengan kehihan adat di desa Bayung Gede menyatakan dapur merupakan simbol tentang kehidupan di sana ada tungku api. Api adalah simbol dewa Brahma yaitu desa pencipta kehidupan. Api bisa juga diartikan sebagai sarana pelebur karena bisa membakar, sehingga segala aktivitas ritual daur hidup di desa ini dilakukan didapur. Pembersihan didapur dapat dimaknai sebagai 
pembersihan lahir dan bhatin secara lahir karena adanya api yang bisa dipakai sebagai pelebur secara bhatin bisa dimaknai sesuai dengan spirit keagamaan tersebut.

b. Setelah ari-ari bayi ini bersih lalu sang ayah mempersiapkan sarana untuk menaruh/ menggantung airari itu ke setra ari-ari (kuburan ariari). Perlengkapan yang harus disiapkan yaitu sebutir kelapa hijau yang dibelah dua diusahakan sama besar ukurannya. Berbagai bahan anget-anget (sejenis rempah yang dipakai untuk membuat hangat) seperti kunyit, merica, ketumbar dll. Atau istilah balinya disebut boreh ceraken Bali. Selain itu ayah sang bayi juga mempersiapkan pamor (kapur sirih) dan kunyit yang akan di ramu menjadi tengeh (sejenis ramuan obat luka yang mencampur kapur sirih dan kunyit). Sang ayah juga mempersiapkan tali yang terbuat dari bambu yang akan dipakai untuk mengikat ari-ari di batang kayu bukak (sejenis kayu endemik di memiliki getah dan buahnya sering terbuka (bukak).

Tahapan selanjutnya adalah kegiatan utama tradisi ini yang terdiri dari memasukan ari-ari kedalam batok kelapa yang telah ada, lalu membawa ke setra ari-ari dan menaruhnya di pohon bukak.

a. Setelah semuanya siap maka langkah selanjutnya yang dilakukan oleh sang ayah adalah mempersiapkan ari-ari sang bayi untuk digantung ke pohon tersebut. Persiapan dimulai membersihkan kepala supaya hanya tinggal $k a u$ (kulit keras) saja. Lalu ari-ari ini akan diletakkan dengan urutan pertama di taruh adalah uekantikeh (robekan tikar yang terbuat dari daun pandan), lalu di di isi tengeh dan berbagai anget-anget. Benda pelengkap yang juga harus ada di dalam tempurung kelapa bersama dengan ari-ari itu adalah ngaad (pisau dari kulit bambu) dan sepit (jepitan bambu). Pada awalnya kedua benda ini berfungsi sebagai pemotong ari-ari yang menghubungkan tali plasenta bayi dan ibunya dan sepit itu berfungsi sebagai penjepit supaya steril dan tidak bersentuhan langsung dengan tangan dukun atau penolong ketika lahir. Namun kini fungsi itu telah digantikan dengan peralatan dokter yang modern. Walaupun demikian masyarakat di Desa Bayung Gede tetapi mengisi itu karena mereka memiliki kepercayaan dan makna lain dari sekedar makna riilnya. Ngaad yang tajam itu memiliki nilai simbolik ketajaman pikiran dan kehebatan sang anak nantinya. Sepit memiliki nilai kebersamaan dan kerjasama. Harapan masyarakat di sini bayi yang lahir ini kelak ketika sudah dewasa mampu hidup bersama dan bekerja sama dalam mewujudkan tujuan hidupnya. Setelah semua itu disiapkan lalu dilengkapi dengan aksara Bali ha, na, ca, ra, ka untuk laki-laki dan bayi perempuan yaitu ha, na, ca yang biasanya di tulis pada daun lontar atau kertas pada zaman sekarang. Tujuan dari penulisan ini supaya nantinya sang anak bisa 
menjadi anak yang pintar. Lalu ditutuplah batok kelapa tersebut dan dilem memakai campuran pamor (kapur sirih) dengan minyak kelapa sehingga kedua bagian kepala tersebut menyatu dan tidak ada lubang atau uus (bocor). Alasan kenapa tidak boleh bocor karena nanti jika bocor maka sang bayi yang punya ari-ari itu mudah sakit dan hidupnya biasanya tidak tenang. Di sini lain dengan tidak bocornya batok kelapa itu menyebabkan bau yang diakibatkan oleh pembusukan ari-ari ini tidak tercium kemana-mana. Ini dibuktikan dengan observasi yang penulis lakukan di kuburan ari-ari ini baunya tidak terlalu menyengat atau busuk walaupun banyak ada ari-ari yang tergantung di sana. Namun apabila benar-benar didekatkan dengan ari-ari yang tergantung memang masih tercium baunya walaupun tidak begitu kuat. Kemudian setelah dilem dengan ramuan pamor dan minyak kepala itu, langkah selanjutnya ada mengikat dengan tali bambu itu. Cara pengikatannya ini harus ngempat (menyilang empat) yang oleh orang bayung gede disebut dengan salang tabu. Berdasarkan wawancara dengan I Wayan Nyabuh makna slang tabu ini adalah sama dengan representasi dari suastika. Suastika adalah lambang suci dalam agama Hindu yang merupakan hasil sulih suara dari suastyastu yang bermakna semoga selalu dalam keadaan baik. Ini membuktikan ada harapan dari sang orang tua kepada anaknya supaya selalu dalam keadaan baik dan direstui oleh Ida Sang Hyang Widhi. Selain itu, ikatan salang tabu yang di buat seperti itu juga sangat kuat dan bisa bertahan lama ini memiliki fungsi supaya ari-ari yang tergantung itu bisa bertahan lama di atas dan tidak mudah jatuh ke tanah.

b. Setelah semua prosesi pemasukan ari-ari ke dalam batok kelapa selesai ayah sang bayi segera berpakaian adat Bali dan membawa taah (sebutan untuk parang dalam bahasa bali) yang dipakai sebagai alat untuk memotong. Taah yang dibawa harus di selet (ditaruh dipinggang). Makna berpakaian adat Bali menurut tokoh desa adalah mengingatkan kepada sang bayi akan budaya dan adat istiadat Bali, sehingga ke depannya bisa menjaga dan melestarikan budaya Bali. Taah yang diselet ini menandakan bahwa sang ayah sudah mempersiapkan diri dalam menghadapi kehidupan, ini diharapkan menular pada sang bayi nantinya dalam mennjalani hidup harus selalu siap menghadapi tantangan dan memperiapkan diri dengan membawa peralatan hidup salah satunya taah itu dan yang lainnya seperti ilmu pengetahuan dan sebagainya. Sang ayah membawa taahsecara riil memiliki fungsi sebagai alat yang dipakai untuk memotong pohon atau dahan kayu bukak yang dipakai tempat untuk menaruh atau menggantung ari-arinya. Ketika hendak 
membawa ari-ari ke kuburan tersebut ada beberapa aturan yang harus diperhatikan pertama, mengambil ari-ari tidak boleh sembarangan yakni mengikuti aturan mengambil pertama selalu harus dengan tangan kanan. Lalu dipindahkan dan dijinjing dengan tangan kiri. Begitu juga ketika meletakkan di pohon harus dipindahkan ketangan kanan dulu baru bisa menaruh. Ini bermakna jika mengawali sesuai harus dengan hal yang baik (kanan berkonotasi positif), ini juga merupakan sebuah pengharapan dari orang tua kepada sang anak kelak bisa menjadi generasi yang memiliki budi pekerti luhur.

c. Ari-ari yang sudah disiapkan itu dibawa ke kuburan oleh sang ayah. Ketika membawa ini sang ayah dilarang untuk bertegursapa dengan orang atau tolah toleh (melihat ke sana kemari), dia harus fokus dan berjalan lurus ke arah kuburan ariari tersebut. Alasan mengapa begitu karena diharapakan sang bayi nantinya setelah dewasa fokus pada tujuan hidupnya sehingga tidak mudah terombangambing atau terperangaruh pada hal-hal negatif dalam menjalani hidup. Selain itu bisa juga dilihat dalam perspektif supaya lebih cepat sampai pada tujuan karena sang ayah sedang membawa ari-ari supaya tidak berbau atau lama berada di jalan sehingga mempercepat selesainya prosesi ini.

d. Ketika sampai di kuburan sang ayah mencari pohon bukak yang hendak dijadikan tempat untuk menggantungkan ari-arinya. Ada dua pilihan yang bisa dilakukan oleh sang ayah bayi ini mencari pohon baru atau menaruh dipohon bukak yang sebelumnya sudah ada ari-ari atau mencari pohon baru yang memang belum ada ari-ari lain yang berada di sana. Namun umumnya orang tua atau sang ayah ini akan menaruh di pohon yang sudah ada ari-arinya dengan alasan supaya ada temannya. Berdasarkan wawancara dengan beberapa orang tua yang pernah menaruh ari-ari bayinya di sana, umumnya mereka memilih pohon yang sudah ada menggantung ari-ari sebelumnya. Ini dilakukan supaya sang anak kelak tidak hanya hidup sendiri saja namun bisa hidup bersama dengan orang lain. Setelah menemukan pohon yang hendak dipakai sebagai tempat untuk menggantungkan itu maka dipotong dengan taah yang dibawa itu lalu air-ari yang awal dijinjing dengan tangan kiri dipindah ke tangan kanan lalu ditaruh, sang ayah pun meninggalkan ari-ari tersebut tergantung dengan tali bambunya. Perlu diingat ketika meletakkan ini tidak ada sesajen ataupun doa-doa khusus yang disampaikan oleh sang ayah jadi ari-ari itu hanya digantung begitu saja. Berikut ini gambar ari-ari yang sudah digantung didapan pokon bukak di setra ari-ari Bayung Gede. 


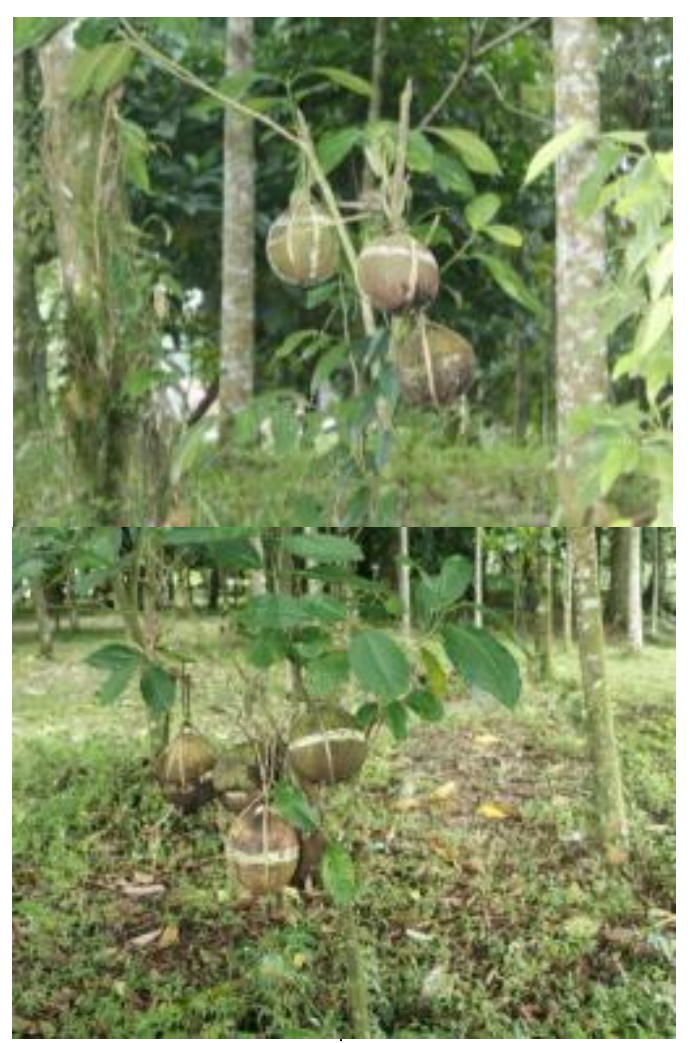

Gambar: Ari-ari yang digantung pada pohon bukak di Desa Bayung Gede Sumber: Dokumentasi I Wayan Putra Yasa, 2015

Tahapan terkahir dari tradisi ini adalah ketika sang ayah pulang dan keluarga yang memiliki bayi ini masuk sebagai keluarga yang cuntaka (tidak suci secara agama Hindu).

a. Ketika pulang sang ayah mencari paku-pakuan/ pakis yang nantinya dipakai sebagai sawen atau tanda bahwa dia memiliki seorang bayi yang baru lahir. Pakis yang dipakai adalah paku angang (pakis endemik yang memiliki duri). Jumlah paku yang diambil memakai ukuran acekel (segenggam tangan ayah sang bayi) tidak boleh lebih ataupun kurang. Paku angang ini dipilih karena ada kepercayaan di desa Bayung gede, bahwa paku angang ini ada representasi dari pemimpin desa mereka atau leluhur mereka bahwa pada jaman dahulu pemimpinnya telah pergi ke Gunung Agung untuk ngayah(melakukan pekerjaan secara tulus ikhlas sebagai wujud syukur dan bhakti kepada Tuhan Yang Maha Esa).Paku Angang inilah sebagai representasi kehadiran pemimpin mereka di dalam kehidupan dan pemimpin yadnya yang dilaksanakan di desa Bayung Gede. Oleh karena itu juga setiap upacara di desa Bayung Gede selalu memakai sarana paku angang tersebut. Namun karena paku tersebut keberadaanya sudah sangat jarang dan sulit di cari, pakuyang diambil sekarang sudah bergeser tidak sama dengan paku yang awalnya ada di desa Bayung Gede khususnya dikuburan tersebut. Menurut penglisir di desa Bayung Gede sekarang paku yang dipakai namanya paku belig.

b. Setelah sesampainya di rumah, paku yang dibawa tadi oleh sang ayah paku ini diletakkan di depan pintu masuk rumah keluarga yang memiliki bayi. Menurut kelihan adat Bayung Gede tidak ada aturan yang membedakan dimana meletakan paku tersebut dikanan atau di kiri pintu masuk rumah. Yang pasti paku itu mudah dilihat sehingga masyarakat sekitar yang lewat mengetahui bahwa di sana ada bayi yang baru lahir. Dalam perkembangan selanjutnya ada juga warga yang mengikatkannya pada sebatang bambu di depanrumahnya, 
namun tetap dengan tujuan memberikan tanda bahwa di rumah itu ada bayi yang baru dilahirkan.

c. Orang tua yang memiliki bayi dan keluarga yang tinggal di pekarangan rumah tersebut selanjutnya disebut sebagai keluarga yang masih cuntaka (kotor), sehingga mereka dilarang untuk memasuki tempat suci yaitu pura. Cuntaka bagi yang memiliki bayi waktu pelaksanaannya terbagi menjadi dua yaitu 12 hari dan 42 hari. Cuntaka yang 12 hari ini diberlakukan kepada mereka yang memiliki anak ke dua, ke tiga dan seterusnya. Sedangkan yang memiliki bayi pertama cuntaknya selama 42 hari. Perbedaan masa cuntaka yaitu 12 dan 42 hari ini disebabkan karena orang tua yang memiliki anak pertama dianggap belum begitu paham dalam mengurus bayi sehingga diberikan masa cuntaka dan bebas dari kegiatan yadnya di desa lebih lama sedangkan bagi mereka yang sudah memiliki anak lebih dari satu dianggap sudah memiliki pemahaman dan juga bisa mengurus anak lebih baik dari pada mereka yang baru pertama kalinya sehingga masa cuntaka mereka pun lebih pendek. Selama cuntaka ini biasanya tetangga atau keluarga yang ada tidak boleh ke rumah tersebut karena jika kesana maka akan ikut cuntaka. Namun demikian cuntaka tidak lama yaitu 24 jam. Ketika yang bersangkutan sudah sempat tidur maka cuntakasudah dianggap hilang.
Khusus untuk pengurus desa dan juga para kubayan dan yang lainnya biasanya tidak ada yang datang karena mereka jika hadir di rumah itu maka di anggap cuntaka juga dan tidak bisa memimpin kegiatan agama di pura sebelum mereka melakukan pembersihan dengan upakaramelukat yang biasanya memerlukan biaya yang cukup mahal sampai sejutaan, sehingga jarang ada yang melanggar kecuali karena keluarga dekat atau yang melahirkan di dalam pekarangannya sendiri. Upacara 12 hari disebut ngerorasin (rorassama artinya dengan 12 dalam bahasa Bali) dan 42 hari disebut dengan upacara tutugkambuhan. Setalah 12 hari bagi orang tua yang memiliki anak ke 2 dan seterus atau 42 hari bagi anak pertama, maka orang tua sang bayi membuatkan upacara ngelepas aon yang dicirikan dengan adanya tipat lepas sejumlah anggota keluarga yang ada di keluarga itu. Jika ini adalah anak pertama maka jumlah tipat lepasnya adalah tiga buah masing-masing satu ketupat mewakili satu orang anggota keluarganya. Setelah diupacarai tipat ini diletakkan ditempat menaruh paku angang yang dipakai tanda ketika bayi lahir. Keberadaan ketupat ini sekaligus tanda atau simbol pemberitahuan kepada warga masyarakat yang lain bahwa keluarga tersebut sudah tidak cuntaka lagi.

Demikianlah rangkaian upacara ari-ari megantung yang dilaksanakan oleh masyarakat Bayung Gede.Secara 
umum ini merupakan suatu keunikan yang satu-satunya ada di Bali oleh sebab itu perlu untuk terus dilestarikan keberadaanya.Keunikan yang dimiliki oleh tradisi ini telah dijadikan salah satu daya tarik wisata oleh dinas kebudayaan kabupaten Bangli dengan menetapkan Desa Bayung Gede sebagai salah satu desa budaya.

\section{Nilai Pendidikan karakter yang terdapat dalam Tradisi Ari-ari Megantung}

Pendidikan karakter secara substansial adalah penanaman karakter (nilai, norma, ideologi) yang dianggap ideal lewat pendidikan di sekolah tanpa mengabaikan lembaga lainnya, dengan sasaran mewujudan manusia berbudi pekerti luhur, tidak saja pada kognisi, tetapi juga pada sikap dan tindakan (Wacik (2011). Pendidikan Karakter termuat dalam rumusan Badan Standar Nasional Pendidikan ( BNSP ) yaitu pendidikan yang menginternalisasikan semua potensi peserta didik seperti hal yang termaktub dalam rumusan tujuan KTSP. Hal ini sesuai dengan tujuan KTSP yaitu meletakkan dasar - dasar kecerdasan, pengetahuan, kepribadian, akhlak mulia, serta keterampilan untuk hidup mandiri dan mengikuti pendidikan selanjutnya (Mulyana, 2008:22). Selanjutnya menurut Supriyatna Pendidikan karakter jika ingin efektif dan utuh mesti menyertakan tiga basis desain dalam pemrogramannya. Tanpa tiga basis itu, program pendidikan karakter di sekolah hanya menjadi wacana semata.Pertama, desain pendidikan karakter berbasis kelas.Kedua, desain pendidikan karakter berbasis kultur sekolah. Dan Ketiga, desain pendidikan karakter berbasis komunitas. Dalam mendidik,komunitas sekolah tidak berjuang sendirian. Dalam konteks ini maka keberadaan tradisi dan nilai adat istiadat yang dianut oleh masyarakat menjadi penting dilihat termasuk di sini nilai pendidikan dan karakter yang ada dalam tradisi ari-ari megantung.

Berdasarkan konsep pendidikan karakter itu maka nilai karakter yang ada pada Tradisi Ari-ari Megantung bisa kita uraikan dalam beberapa hal berikut.

1) Nilai religius

Nilai religius menurut Sulhan (2010) adalah sikap dan perilaku yang patuh dalam melaksanakan ajaran agama yang dianutnya, toleran terhadap pelaksanaan ibadah agama lain, dan hidup rukun dengan pemeluk agama lain. Nilai itu ada pada tradisi Ari-ari Megantung di Bayung Gede, yakni dengan adanya pemaknaan bahwa tradisi Ari-ari Megantung ini merupakan bentuk nyata dari rasa hormat dan menghargai pemberian dari Ida Sang Hyang Widhi, oleh karena itu dilarang keras untuk melakukan tindakan yang tidak sesuai dengan tata aturan yang telah ditetapkan. Karena jika hal itu dilakukan maka dapat menyebabkan anak dan keluarganya akan mendapatkan hukum karmaplaha negative yang bisa merusak dan menghancurkan dirinya sendiri dan juga desa Bayung Gede secara keseluruhan. Oleh karena itu sampai saat ini 
belum ada masyarakat Bayung Gede yang berani melanggar atau tidak melaksanakan tradisi Ari-ari Megantung.

Bentuk nyata nilai religius lainnya yaitu adanya upacara lepas aon ketika bayi berusia 12 hari dan 42 hari yang dilaksanakan dengan upacara agama Hindu.

Nilai religius juga bisa dilihat dari harapan dan doa-doa yang selalu dipanjatkan kepada Tuhan supaya anaknya yang memiliki Ari-ari Megantung bisa hidup dengan baik menjaga tradisi leluhur.

2) Nilai kerja keras

Adanya keharusan untuk membawa peralatan yaitu berupa parang untuk memotong kayu bukak tempat menaruh ari-ari megantung itu tidak semata sebagai alat, namun menurut tetua di desa Bayung Gede itu adalah simbolisasi kesiapan kita dalam menjalani hidup yaitu dengan bekerja keras.Ini bisa dimaknai demikian karena umumnya pekerjaan masyarakat di desa Bayung Gede adalah seorang petani, keberadaan parang itu adalah hal yang wajib adanya dalam kehidupan keseharinnya. Ini sejalan dengan pemikiran Sulhan (2010) dapat dilihat dari perilaku yang menunjukkan upaya sungguhsungguh dalam mengatasi berbagai hambatan belajar dan tugas, serta menyelesaikan tugas dengan sebaik-baiknya. Kesungguhsungguhan bisa dilihat dari larangan kepada sang ayah yang membawa ari-ari untuk tidak melihat kesana kemari tetapi tetap fokus pada tujuannya yaitu setra ari-ari yang menjadi lokasi tempat ari-ari itu akan digantungkan. Sang ayah harus menyelesaikan semua tahapan itu secara benar dan tidak setengah-setengah.Oleh karena itu kerja keras dalam membersihan sampai pada penyelesaian prosesi itu perlu untuk ditauladani dan dijadikan panutan oleh generasi selanjutnya.

3) Nilai toleransi

Menurut Sulhan (2010) toleransi adalah sikap dan tindakan yang menghargai perbedaan agama, etnis, pendapat, sikap, dan tindakan orang lain yang berbeda dari dirinya. Nilai toleransi ini bisa dijumpai pada pemberian kebebasan kepada orangtua yang memiliki bayi untuk tidak mengikuti kegiatan di adat dengan lamanya waktu yang berbeda yaitu 12 hari untuk mereka yang sudah memiliki anak lebih dari satu artinya bukan anak pertama dan memberikan kebebasan dari adat selama 42 hari bagi orangtua yang memiliki anak pertama. Pemberian waktu untuk tidak ikut dalam kegiatan adat karena di anggap cuntaka ini sebenarnya juga bentuk toleransi warga masyarakat Bayung Gede kepada warganya yang memiliki bayi sehingga bisa mengurus bayinya dengan maksimal. Nilai toleransi ini penting ditanamkan di zaman yang modern ini yang sangat mengedepannya individualisme, yang selalu berorientasi pada 
kepentingan diri sendiri dan terkadang lupa dengan kepentingan orang lain. Oleh sebab itu nilai-nilai sejenis ini harus terus dikembangkan dan jaga kelestariannya demi anak-cucu kita kedepannya agar tidak melupakan nilai persaudaraan dan saling menghormati serta bertoleransi dengan sesama.

4) Nilai kebersihan dan kejujuran

Kebersihan berarti bersih fisik, bersih hati, tidak dengki, tidak iri hati, dll dan kejujuran bebas dari praktik-praktik KKN, jangan pernah melanggar hukum, memiliki intergritas, apa yang dilakukan berdasarkan kenyataan, hati dan ucapan sama, apa yang dikatakan benar, dll.(Sulhan, 2010; Wacik, 2011). Kebersihan dan kejujuran bisa dilihat dari persiapan awal Tradisi Ari-ari Megantung, ari-ari yang akan digantung harus dalam kondisi bersih oleh sebab itu sang ayah harus benar-benar memberihkannya. Maknya ini tentunya luas bisa secara fisik itu akan bersih terbebas dari kotoran, bisa juga bersih secara rohani dengan nantinya menjadi generasi yang memiliki pemikiran, sikap, perbuatan bersih dalam kesehariannya. Jika sudah biasa melakukan tindakan bersih yang identik dengan kebenaran tentunya dia juga harus jujur.Jujur artinya bebas dari perbuatan yang tercelabebas dari hal-hal negative.

Simbol kejujuran yang ada dalam tradisi Ari-ari Megantung yaitu dengan memberikan tanda di depan rumahnya berupa paku angang yang ditaruh di depan rumah. Hal ini wajib dilakukan sebagai tanda pemberitahuan kepada masyarakat Bayung Gede yang lainnya bahwa yang bersangkutan sudah memiliki bayi dan dalam keadaan cuntaka.Pemberian tanda itu wajib dilakukan sebagai bentuk riil bahwa keluarga itu telah jujur dan berbuat benar sesuai dengan nilai tradisi dan budaya masyarakat Bayung Gede.

5) Nilai menghormati pada yang dituakan

Menurut wacik (2011) Hormat kepada orang yang dituakan, hormat kepada orang tua, pemimpin, tokoh masyarakat, pejabat, dll. Tradisi Ari-ari Megantung juga mengajarkan kepada generasi muda untuk selalu menghormati dan menjaga nama baik orang tua. Ini bisa diihat dari keharusan dalam memimpin upacara di lepas aon itu adalah salah seorang yang dituakan di desa Bayung Gede.Warga juga dilarang untuk melakukan perbuatan yang bisa mengganggu keberadaan setra ari-ari karena disana tergantung ariari leluhur, saudara atau dirinya sendiri yang harus dihormati dan dijaga keberadaannya. Kebiasaan untuk selalu menghormati orangtua dan tetua atau tokoh desa di Bayung Gede juga bisa dilihat dari adanya kebebasan untuk penglingsir atau tokoh desa untuk tidak menjenguk ke pekarangan 
yang memiliki bayi ini sebagai bentuk penghormatan masyarakat desa Bayung Gede kepada tokoh desanya supaya secara skala dan niskala terjaga kebersihan dan kesuciannya.

6) Nilai tanggungjawab

Tradisi Ari-ari Megantung mengajarkan bagaimana orangtua memiliki tanggungjawab masingmasing yang jelas dan saling melengkapi.Hal ini sejaln dengan pengertian tanggungjawab menurut Sulhan (2010) yang menyatakan bahwa tanggungjawab itu adalah sikap dan perilaku seseorang untuk melaksanakan tugas dan kewajiban, yang seharusnya dilakukan terhadap diri sendiri, masyarakat, lingkungan (alam, sosial, dan budaya), negara, dan Tuhan Yang Maha Esa.Nilai ini terlihat jelas pada pembagian tugas dan tanggungjawab dalam keluarga di Desa Bayung Gede. Masing-masing orangtua memiliki tugas yang jelas yakni Sang ibu mengandung sekitar 9 bulan, selanjutnya ketika anaknya lahir menjadi tanggungjawab sang ayah untuk membersihkan Ari-ari sampai pada menaruhnya di Setra Ari-ari. Kewajiban ini tidak bisa diwakilkan kepada orang lain dan harus dilakukan oleh sang ayah yang bersangkutan, kecuali jika sang ayah sudah tiada baru bisa diwakilkan oleh pihak keluarga lannya. Ini mengajarkan kepada kita, setiap apa yang kita lakukan harus dipertanggungjawabkan sehingga bisa dijadikan panutan, karena di saat ini banyak orang yang bisa berbuat tapi tidak mau menerima resiko perbuatannya atau tidak mau

mempertanggungjawabkan

perbuatan yang telah dilakukan.

\section{Penutup}

Tradisi dan adat istiadat yang ada di daerah merupakan bentuk riil dari rasa percaya masyarakat akan kekuatan yang ada di luar dirinya yang nantinya menciptakan sistem religi. Begitu halnya yang ada pada masyarakat Bayung Gede yang mengkaitkan sejarah tradisi Ari-ari Megantung dengan sejarah desanya yang berasal dari Kayu Selem yang lahir dari sebatang kayu.Oleh karena itu kebiasaan untuk menggantung Ari-ari ini sebagai bentuk penghormatan kepada leluhurnya.Tradisi menggantung ari-ari ini dimulai dari tahapan pembersihan, membawa ke setra ari-ari, menggantungkan sampai pada kembali pulang dengan membawa paku angang.Keluarga yang memiliki bayi selanjutnya memasuki masa cuntaka selama 12 hari bagi yang sudah memiliki bayi lebih dari satu dan 42 hari bagi mereka yang memiliki bayi pertama. Cuntaka keluarga ini berakhir ditandainya dengan upacara pelepas aon dengan menaruh tipat lepas di depan pintu rumah.

Tradisi Ari-ari Megantung ini banyak mengandung nilai karakter yang bisa diwariskan dijadikan panutan bagi generasi muda sekarang ini. Nilai-nalai karakter tersebut antara lain nilai religi, kebersihan dan kejujuran, tanggungjawab, toleransi, menghormati orang yang dituakan, kerja keras dan 
nilai-nilai lainnya yang bisa terus digali. Oleh sebab itu maka perlu ada dilestarikan dan dijaga keberadaannya demi masa depan generasi bangsa dan identitas masyarakat Bayung Gede secara khusus dan Indonesia umumnya.

Daftar Pustaka

Koentjaraningrat. 1984. Kebudayaan Jawa. Jakarta: Balai Pustaka.

Miles, MB and A.M. Huberman.2009. Analisis Data Kualitatif.T. R. Rohidi (penerjemah). Jakarta: UI Press.

Mulyana,E. 2008. Kurikulum Tingkat Satuan Pendidikan. Bandung: Rosdakarya.

Mulyasa,E. 2009. Menjadi Guru Profesional Menciptakan Pembelajaran Kreatif dan udayaan dan Pariwisata.
Menyenangkan.Bandung : Remaja Rosdakarya.

Sudharta, Tjok Rai.2013. Manusia Hindu Dari kandungan sampai Perkawinan.Denpasar: Pustaka Bali Post.

Sulhan, N. 2010. Pendidikan Berbasis Karakter Sinergi antara Sekolah dan Rumah dalam Membentuk Karakter Anak. Surabaya: Jaringpena.

Vansina, Jan. 2014. Tradisi Lisan sebagai Sejarah. Jogyakarta: Ombak.

Wacik, J. 2011. Duapuluh Empat Karakter Modal Membangun Bangsa Menurut Jero Wacik. Jakarta: Kementerian Keb 